\title{
Effect of Antimicrobial Peptides and Chemicals Produced by Animals on Liver Microsomal Enzymes CYP450
}

\author{
Al-Baraa Akram, Glen McCann \\ Department of pharmaceutical biotechnology, De Montfort University, Leicester, UK \\ Email: albraaakram94@gmail.com
}

How to cite this paper: Akram, A.-B. and McCann, G. (2021) Effect of Antimicrobial Peptides and Chemicals Produced by Animals on Liver Microsomal Enzymes CYP450. Advances in Bioscience and Biotechnology, 12, 297-308.

https://doi.org/10.4236/abb.2021.129019

Received: August 11, 2021

Accepted: September 25, 2021

Published: September 28, 2021

Copyright $\odot 2021$ by author(s) and Scientific Research Publishing Inc. This work is licensed under the Creative Commons Attribution International License (CC BY 4.0).

http://creativecommons.org/licenses/by/4.0/

\begin{abstract}
The problem of multidrug-resistant pathogens as bacteria, fungi and yeast in addition to the restriction of using antibiotics as growth promoting substances in feed has attracted attention for looking for alternative sources instead of conventional antibiotics like natural products which have antimicrobial activity. Much interest and researches have been focused on using natural antimicrobial peptides and chemicals extracted from animal secretions and some insect's venoms as they exhibit antimicrobial activity against pathogens with lower resistance and higher synergistic effects if they were given in combination with blends of them. In this paper, some antibacterial peptides extracted from honeybees venom and expression with yeast Saccharomyces cerevisiae will be discussed as well as antimicrobial chemicals extracted from giraffes in addition to their inhibitory effects on liver microsomal enzymes CYP450 will be discussed also with its activity against microorganisms which are Agrobacterium rhizogenes, Aspergillus niger, Candida albicans and E. coli using optical density analysis technique then their minimum inhibitory concentrations (MIC) will be determined as well as ICs 50 to measure the potency to inhibit a biological function using programmes like Gene5, graph pad prism and clone manager as well as testing antimicrobial activity of some chemicals which are provided in animal secretions.
\end{abstract}

\section{Keywords}

Antimicrobials, CYP450, Antimicrobial Peptides

\section{Introduction}

\subsection{Cytochrome P450 Enzymes}

Cytochrome P450 groups are haem containing enzymes responsible for phase 1 
oxidative metabolic reaction; they are not involved in electron transport (cytochrome $b$ and $c$ ). A member of a complex family of microsomal enzymes (mono-oxygenases) is present in the endoplasmic reticulum that detoxifies compounds [1].

\subsection{Peptides of Honeybees}

There have been former study states that total ribonucleic acid has been transcribed from deoxyribonucleic acid from the venom glands of queen bees and cloned into PSTI website of inclusion body pPR322 [2] as there are extremely specialised cells manufacturing giant amounts of polypeptides and play a serious role in organic chemistry analysis; there are varied resources for purification specific mRNAs that had been used for learning macromolecule synthesis in cell free systems which had been thought of as a beginning material for constructing body DNA acid clones which might be considered as a begin purpose to purify and isolate genes. The synthesis of melittin is that the peptide of bee venom (Figure 1), consists of twenty-six amino acids [3] that this lytic peptide is isolated foremost from a primary precursor known as pre-pro-melittin through several pathway steps to rework it into pro-melittin then melittin using different enzymes (Figure 1).

The Giraffe produces these chemicals which might be detected in totally different ways; methylene chloride or DMSO of hair samples of male and female Giraffes were analysed by gas chromatography/mass spectroscopy that produces 2 chemicals which are indole and 3-methyl indole (Figure 2) which are powerfully accountable to the robust scent of the giraffe. Alternative chemical extracts are p-cresol (Figure 2), heptanal, octanal, nonanal, benzaldehyde, octane, hexadecenoic acid and tetra-decanoic acid.

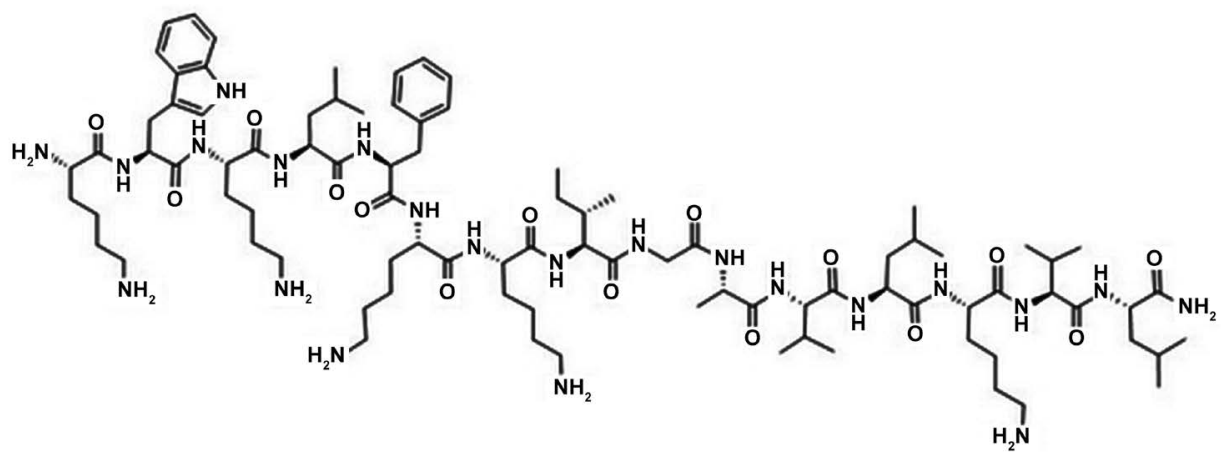

Figure 1. Chemical structure of melittin.<smiles>c1ccc2[nH]ccc2c1</smiles>

Indole<smiles>Cc1c[nH]c2ccccc12</smiles>

Skatole<smiles>Cc1ccc(O)cc1</smiles>

Figure 2. The chemical structure of main chemicals of giraffes' hair indole, skatole and p-cresol. 


\subsection{Cytochrome P450s Activities}

Multiple drug medical care could be a difficult drawback in medication today that crystal rectifier to drug-drug interactions which are magnified hugely thus it's involved in drug analysis and development. Some medications were withdrawn from market as terfenadine and mibefradil thanks to drug-drug interactions [4] [5] thanks to metabolism by CYP450s that are thought of as the main route for drug elimination by the processes of metabolism and excretion.

Inhibition of CYP450s could be a contend at CYP active sites like prosthetic haem iron and substrate-binding region of CYP proteins and therefore the activity of CYPs enzymes may be resorted in vivo and in vitro when depletion. As irreversible inhibitors, most compounds inhibit CYPs act by irreversible binding or they're born-again by CYPs to an energetic matter foremost that bind irreversibly to the positioning at the centre of the accelerator resulting in protein activity permanent loss.

Irreversible loss of the protein activity by remodelling to an energetic matter is completed by CYP-catalysed reaction thus it may be thought of as mechanism-based inhibition and during this case, the reactive matter forms stably advanced with the haem molecule of CYP that is termed similar irreversible inhibition or modifies covalently CYP proteins irreversibly.

Generally, in each of these cases, the protein activity cannot be recovered by retreating the CYP substance from the reaction. In distinction reversible inhibition that the inactivation of CYPs by reactive matter results in future effects on the pharmacology of the medication consists of the processes of absorption, distribution, metabolism and excretion because the inactivated accelerators are replaced by new synthesized CYP enzyme.

Though the bulk of drug-drug interactions are happening by reversible inhibition, the irreversible inhibitors aren't most popular and are avoided in drug formulation and development. As they forever fail within the method of drug development thanks to toxicity and drug-drug interaction in addition as drug-food interaction considerations, it's necessary to grasp drug-drug interaction and therefore the irreversible inhibitors within the early stage of drug development before additional valuable resources are done to compounds that have less likelihood to pass to the hospitals or clinics.

Though a lot of serious issues are caused by irreversible inhibition of CYPs in drug formulation, differentiation between reversible and irreversible isn't the main issue for CYP screening approaches that the irreversible inhibition of CYP450 in mammals' granule enzymes are known liquid natural process (LC) or LC-MS/MS to analyse metabolites of the marker. This effortful and high-value assay limits the flexibility to handle compounds with high volumes and it's been a big obstacle for screening the irreversible inhibitors throughout drug development however recently, synthesis and drug screening of drug discovery led to high numbers of drug Candidates.

The requirement for higher ways to screen irreversible inhibitors became terribly clear, during this paper, we've investigated the flexibility and result of inhi- 
bition between chemicals indole, alkyl group indole, p-cresol and mix of those 3 chemicals that are extracted from Giraffe hair victimisation DMSO on three forms of liver granule enzymes CYP1A1, CYP1A2 and CYP1B1 to tell apart between the result of every chemical one by one and screen the synergistic effect of their combination to dilute the nephrotoxic effect of p-cresol and cut back the antimicrobial resistance at constant time.

\section{Materials and Methods}

\subsection{CYP450 Protocols}

The typical parameters used for fluorescent substrates using microsomal P450s is by adjusting conditions' assays per $100 \mu \mathrm{L}$ volumes, black 96 well plates and $100 \mathrm{mM}$ potassium phosphate buffer with $\mathrm{PH}$ 7.4. Regenerating system is by frozen solution A and solution B

Regenerating system solution A stock is held by $65.42 \mathrm{mM}$ magnesium chloride solution containing $26.13 \mathrm{mM} \mathrm{NADP}^{+}$and $65.77 \mathrm{mM}$ of glucose-6phosphate. In each well $\mathrm{NADP}^{+} 1.3 \mathrm{mM}$, glucose-6-phosphate $3.3 \mathrm{mM}$ in magnesium chloride buffer $3.3 \mathrm{mM}$.

Regenerating system solution B stock $5 \mathrm{mM}$ tribasic sodium citrate contains 40 units per $\mathrm{ml}$ of glucose-6-phosphate dehydrogenase. In each well 0.04 units of glucose-6-phosphate dehydrogenase in buffer sodium citrate $50 \mu \mathrm{M}$.

General conditions:

1) Concentration of final well substrate is 2 to $15 \mu \mathrm{M}$;

2) Concentration of final well $\mathrm{P} 450$ volumes is $0.5 \mu \mathrm{L}$ to $4 \mu \mathrm{L}$ according to $\mathrm{P} 450$;

3) Concentration of final well of the solvent is aimed to keep at $0.5 \%$ but it can go towards 1\%. Usually use acetonitrile/DMSO for substrates/inhibitor testing;

4) Keep the temperature of the reaction at $37^{\circ} \mathrm{C}, 30^{\circ} \mathrm{C}$ is good and acceptable;

5) These reactions are linear from 20 min to 1 hour according to P450 and set-up conditions;

6) Make the required multiplies of $\mathrm{P} 450$ mixture by diluting the required volume of a total volume of $50 \mu \mathrm{L}$ in $100 \mathrm{mM}$ potassium phosphate buffer $\mathrm{PH} 7.4$ and then dispense $50 \mu \mathrm{L} /$ well after that add master mix to every well.

\section{Master mix standards (Table 1):}

$25 \mu \mathrm{L} 200 \mathrm{mM}$ potassium phosphate buffer PH 7.4 top up to give the final volume $50 \mu \mathrm{L}$ of water:

$5 \mu \mathrm{L}$ solution $\mathrm{A}$;

$1 \mu \mathrm{L}$ solution $\mathrm{B}$.

Table 1. Assay parameters per reaction showing P450 families, name of substrate, final well substrate by $\mu \mathrm{M}$, volumes of P450s $\mu \mathrm{L} /$ well and volume of $100 \mathrm{mM}$ potassium phosphate $\mu \mathrm{L}$.

\begin{tabular}{ccccc}
\hline P450 & Substrate & Final well [Substrate] $\mu \mathrm{M}$ & Volume of P450s $\mu \mathrm{L}$ per well Volume of $100 \mathrm{mM} \mathrm{K}$ phosphate $\mu \mathrm{L}$ \\
\hline CYP1A1 & EROD & 5 & 1 & 49 \\
CYP1A2 & CEC & 15 & 1 & 49 \\
CYP1B1 & EROD & 5 & 1 & 49 \\
\hline
\end{tabular}


Substrate is normally between $0.1 \mu \mathrm{L}$ to $0.5 \mu \mathrm{L} /$ well, normally fix the volume to avoid P450 solvent destruction.

\subsection{CYP Inhibition}

Studying CYP450 inhibition is very important because it measures the effect of the chemicals on the liver enzymes and screens the metabolism of liver function; it is also useful in studying drug-drug interactions, drug-food interactions, drugexcipient interactions and drug-gene interactions.

\subsection{CYP1A2 Assays}

Prepare blend of indole, skatole and p-cresol by taking 1/50 dilution of $100 \mathrm{mM}$ Cresol, $1 / 250$ dilution of $500 \mathrm{mM}$ indole and 1/125 dilution if $250 \mathrm{mM}$ of skatole to get mixture consists of:

$20 \mu \mathrm{L}$ of cresol in $980 \mu \mathrm{L}$ of $10 \%$ DMSO; $10 \mu \mathrm{L}$ in $2490 \mu \mathrm{L}$ of $10 \%$ DMSO; 10 $\mu \mathrm{L}$ of skatole in $1240 \mu \mathrm{L}$ of DMSO.

Prepare stock solution consists of CYP1A2 mixed with substrate CEC (3-cyano-7-ethocxycoumarin), $0.5 \mathrm{M}$ with $\mathrm{PH} 7.4$ of potassium phosphate buffer. Put the stock with cresol in the first three columns, indole in the next three columns, skatole in the next three columns and blend in the last three columns. Put DMSO (dimethyl sulfoxide) in all wells.

In a clear 96 well plate put cresol, indole, skatole and blend in the first four wells individually and as before Insert $200 \mu \mathrm{L}$ of $2 \mathrm{mM}$ of stock from the first raw and transfer from it $100 \mu \mathrm{L}$ in $100 \mu \mathrm{L} 10 \%$ DMSO in to the second raw then transfer $100 \mu \mathrm{L}$ in $100 \mu \mathrm{L}$ of DMSO in the third raw then transfer $20 \mu \mathrm{L}$ from the third raw to the forth raw with $180 \mu \mathrm{L}$ of DMSO, then transfer from it $100 \mu \mathrm{L}$ in $100 \mu \mathrm{L}$ in $10 \%$ DMSO to the fifth raw then transfer $100 \mu \mathrm{L}$ in $100 \mu \mathrm{L}$ of DMSO in the sixth raw then add $20 \mu \mathrm{L}$ in $180 \mu \mathrm{L}$ of $10 \%$ DMSO in the $7^{\text {th }}$ raw and in the $8^{\text {th }}$ raw transfer $100 \mu \mathrm{L}$ in $200 \mu \mathrm{L}$ DMSO.

In the last raw put $200 \mu \mathrm{L}$ of DMSO as a positive control and add $0.5 \mathrm{M}$ tris base acetonitrile as a killing and stop solution which is considered a negative control and consists of $80 \%$ acetonitrile and $20 \%$ tris OSM not PHed as the concentration of pure acetonitrile is $10 \mathrm{mM}$ (Table 2).

Add substrate solution A which is buffer consists of NADPH glucose-6-phosphate magnesium chloride and enzyme solution B glucose-6-phosphate dehydrogenase tribasic sodium citrate to form master mix in a petri dish which consists of:

$20 \mu \mathrm{L}$ of CEC (cyano-7-ethocxycoumarin);

$3250 \mu \mathrm{L}$ potassium phosphate;

$650 \mu \mathrm{L}$ solution A;

$130 \mu \mathrm{L}$ solution $\mathrm{B}$;

$2450 \mu \mathrm{L}$ distilled water.

Mix them gently and pipette $50 \mu \mathrm{L}$ to each well in 96 black well plate then measure the rate of inhibition using gen5 software which will produce this (Figure 3). 
Table 2. Scheme of the contents with concentrations of the 96 well plate showing their concentations.

\begin{tabular}{|c|c|c|c|c|c|c|c|c|c|c|c|c|c|}
\hline \multirow{2}{*}{ Wells } & \multirow{2}{*}{ Dilutions } & 1 & 2 & 3 & 4 & 5 & 6 & 7 & 8 & 9 & 10 & 11 & 12 \\
\hline & & \multicolumn{3}{|c|}{ Cresol } & \multicolumn{3}{|c|}{ Indole } & \multicolumn{3}{|c|}{ Skatole } & \multicolumn{3}{|c|}{ Blend } \\
\hline A & Stock & $100 \mu \mathrm{M}$ & $100 \mu \mathrm{M}$ & $100 \mu \mathrm{M}$ & $2000 \mu \mathrm{M}$ & $2000 \mu \mathrm{M}$ & $2000 \mu \mathrm{M}$ & $2000 \mu \mathrm{M}$ & $2000 \mu \mathrm{M}$ & $2000 \mu \mathrm{M}$ & $2000 \mu \mathrm{M}$ & $2000 \mu \mathrm{M}$ & $2000 \mu \mathrm{M}$ \\
\hline B & $1 / 2$ & $50 \mu \mathrm{M}$ & $50 \mu \mathrm{M}$ & $50 \mu \mathrm{M}$ & $1000 \mu \mathrm{M}$ & $1000 \mu \mathrm{M}$ & $1000 \mu \mathrm{M}$ & $1000 \mu \mathrm{M}$ & $1000 \mu \mathrm{M}$ & $1000 \mu \mathrm{M}$ & $1000 \mu \mathrm{M}$ & $1000 \mu \mathrm{M}$ & $1000 \mu \mathrm{M}$ \\
\hline $\mathrm{C}$ & $1 / 2$ & $25 \mu \mathrm{M}$ & $25 \mu \mathrm{M}$ & $25 \mu \mathrm{M}$ & $500 \mu \mathrm{M}$ & $500 \mu \mathrm{M}$ & $500 \mu \mathrm{M}$ & $500 \mu \mathrm{M}$ & $500 \mu \mathrm{M}$ & $500 \mu \mathrm{M}$ & $500 \mu \mathrm{M}$ & $500 \mu \mathrm{M}$ & $500 \mu \mathrm{M}$ \\
\hline $\mathrm{D}$ & $1 / 10$ & $2.5 \mu \mathrm{M}$ & $2.5 \mu \mathrm{M}$ & $2.5 \mu \mathrm{M}$ & $50 \mu \mathrm{M}$ & $50 \mu \mathrm{M}$ & $50 \mu \mathrm{M}$ & $50 \mu \mathrm{M}$ & $50 \mu \mathrm{M}$ & $50 \mu \mathrm{M}$ & $50 \mu \mathrm{M}$ & $50 \mu \mathrm{M}$ & $50 \mu \mathrm{M}$ \\
\hline $\mathrm{E}$ & $1 / 2$ & $1.25 \mu \mathrm{M}$ & $1.25 \mu \mathrm{M}$ & $1.25 \mu \mathrm{M}$ & $25 \mu \mathrm{M}$ & $25 \mu \mathrm{M}$ & $25 \mu \mathrm{M}$ & $25 \mu \mathrm{M}$ & $25 \mu \mathrm{M}$ & $25 \mu \mathrm{M}$ & $25 \mu \mathrm{M}$ & $25 \mu \mathrm{M}$ & $25 \mu \mathrm{M}$ \\
\hline $\mathrm{F}$ & $1 / 2$ & $0.625 \mu \mathrm{M}$ & $0.625 \mu \mathrm{M}$ & $0.625 \mu \mathrm{M}$ & $12.5 \mu \mathrm{M}$ & $12.5 \mu \mathrm{M}$ & $12.5 \mu \mathrm{M}$ & $12.5 \mu \mathrm{M}$ & $12.5 \mu \mathrm{M}$ & $12.5 \mu \mathrm{M}$ & $12.5 \mu \mathrm{M}$ & $12.5 \mu \mathrm{M}$ & $12.5 \mu \mathrm{M}$ \\
\hline G & $1 / 10$ & $62.5 \mathrm{nM}$ & $62.5 \mathrm{nM}$ & $62.5 \mathrm{nM}$ & $1.25 \mu \mathrm{M}$ & $1.25 \mu \mathrm{M}$ & $1.25 \mu \mathrm{M}$ & $1.25 \mu \mathrm{M}$ & $1.25 \mu \mathrm{M}$ & $1.25 \mu \mathrm{M}$ & $1.25 \mu \mathrm{M}$ & $1.25 \mu \mathrm{M}$ & $1.25 \mu \mathrm{M}$ \\
\hline $\mathrm{H}$ & & \multicolumn{9}{|c|}{$200 \mu \mathrm{L}$ DMSO } & \multicolumn{3}{|c|}{$10 \mathrm{mM}$ Acetonitrile } \\
\hline
\end{tabular}

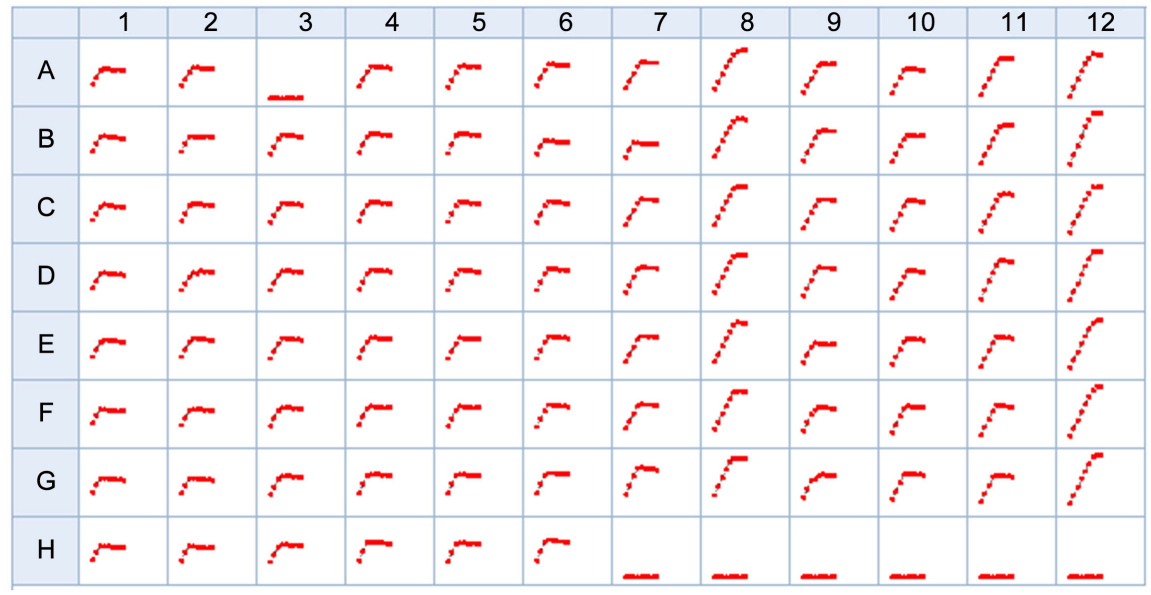

Figure 3. Explanation figure shows the inhibition grades of CYP1A1, distant points refer to low inhibition, closed or near points refer to high inhibition and flat point for negative controls resulted from using stop solution acetonitrile tris.

Transfer your data into excel sheet and divide data related to blend on 3 to obtain the inhibition effect of each chemical individually within the combination. Calculate the mean, standard deviation and standard error of the mean for both positive and negative control values. Calculate the percentage of inhibition by the law:

$\%$ of inhibition $=100-(($ amount of inhibition $/$ mean value of the positive control) $\times 100$ ).

\subsection{CYP1A1 Assays}

1) In a new clear 96 well plate put cresol, indole, skatole and blend in the first four wells individually and as before Insert $200 \mu \mathrm{L}$ of $2 \mathrm{mM}$ of stock from the first raw and transfer from it $100 \mu \mathrm{L}$ in $100 \mu \mathrm{L} 10 \%$ DMSO in to the second raw then transfer $100 \mu \mathrm{L}$ in $100 \mu \mathrm{L}$ of DMSO in the third raw then transfer $20 \mu \mathrm{L}$ from the third raw to the forth raw with $180 \mu \mathrm{L}$ of DMSO, then transfer from it $100 \mu \mathrm{L}$ in $100 \mu \mathrm{L}$ in $10 \%$ DMSO to the fifth raw then transfer $100 \mu \mathrm{L}$ in $100 \mu \mathrm{L}$ of DMSO in the sixth raw then add $20 \mu \mathrm{L}$ in $180 \mu \mathrm{L}$ of $10 \%$ DMSO in the $7^{\text {th }}$ raw 
and in the $8^{\text {th }}$ raw transfer $100 \mu \mathrm{L}$ in $200 \mu \mathrm{L}$ DMSO.

2) In the next successive four wells dilute with $60 \mu \mathrm{L}$ water and $80 \mu \mathrm{L}$ of 200 $\mathrm{mM} \mathrm{KPI}$ which is phosphate buffer consists of $0.6 \mathrm{ml}$ of $1 \mathrm{M} \mathrm{K} 2 \mathrm{HPO} 4+9.4 \mathrm{ml}$ of $1 \mathrm{M} \mathrm{KH} 2 \mathrm{PO} 4$ mixed and made up to $50 \mathrm{ml}$ with sterile ultra-pure water. and pipette $20 \mu \mathrm{L}$ cresol from the first column with them in the $6^{\text {th }}$ column, $20 \mu \mathrm{L}$ indole from second column in the $7^{\text {th }}$ column, $20 \mu \mathrm{L}$ skatole from the third column in the $8^{\text {th }}$ column and $20 \mu \mathrm{L}$ blend from the $4^{\text {th }}$ column in $9^{\text {th }}$ column (Table 3 ).

Prepare master mix from CYP $1 \mathrm{~A} 1$ and KPI by the ratio 1:130.

$1 \mu \mathrm{L}$ CYP $1 \mathrm{~A} 1 * 130=130 \mu \mathrm{L}$;

$9 \mu \mathrm{L}$ KPI ${ }^{*} 130=1170 \mu \mathrm{L}$.

In Eppendorf tube prepare CYP mix by mixing $1170 \mu \mathrm{L}$ of $100 \mathrm{mM}$ KPI and $130 \mu \mathrm{L}$ of CYP $1 \mathrm{~A} 1$ and pipette $10 \mu \mathrm{L}$ in each well of a black 96 well plate.

Note: in each well add KPI first before addition of water.

In the black 96 well plate:

take $40 \mu \mathrm{L}$ of the $6^{\text {th }}$ clear column and transfer it into black columns 1,2 and 3 , take $40 \mu \mathrm{L}$ of the $7^{\text {th }}$ clear column and transfer it into black columns 4,5 and 6 , take $40 \mu \mathrm{L}$ of the $8^{\text {th }}$ clear column and transfer it into black columns 7, 8 and 9 , take $40 \mu \mathrm{L}$ of the $9^{\text {th }}$ clear column and transfer it into black columns 10,11 and 12.

In the last down 6 wells in the right pipette $75 \mu \mathrm{L}$ of acetonitrile stop solution to potassium phosphate buffer and CYP1A1 as a negative control. Prepare master mix in a petri dish which consists of:

$3250 \mu \mathrm{L} 200 \mathrm{mM}$ potassium phosphate buffer;

$70 \mu \mathrm{L} 1 \mathrm{mM}$ stock EROD substrate (7-ethoxyresorufin O-deethylation);

$650 \mu \mathrm{L}$ solution $\mathrm{A}$;

$130 \mu \mathrm{L}$ solution $\mathrm{B}$;

$2405 \mu \mathrm{L}$ distilled water.

Mix them gently and pipette $50 \mu \mathrm{L}$ to each well in 96 black well plate then measure the rate of inhibition using gen 5 software. Transfer your data into excel sheet and divide data related to blend on 3 to obtain the inhibition effect of each chemical individually within the combination. Calculate the mean, standard deviation and standard error of the mean for both positive and negative control values. Calculate the percentage of inhibition by the law:

Table 3. scheme of the contents of the clear 96 well plate showing their diluents.

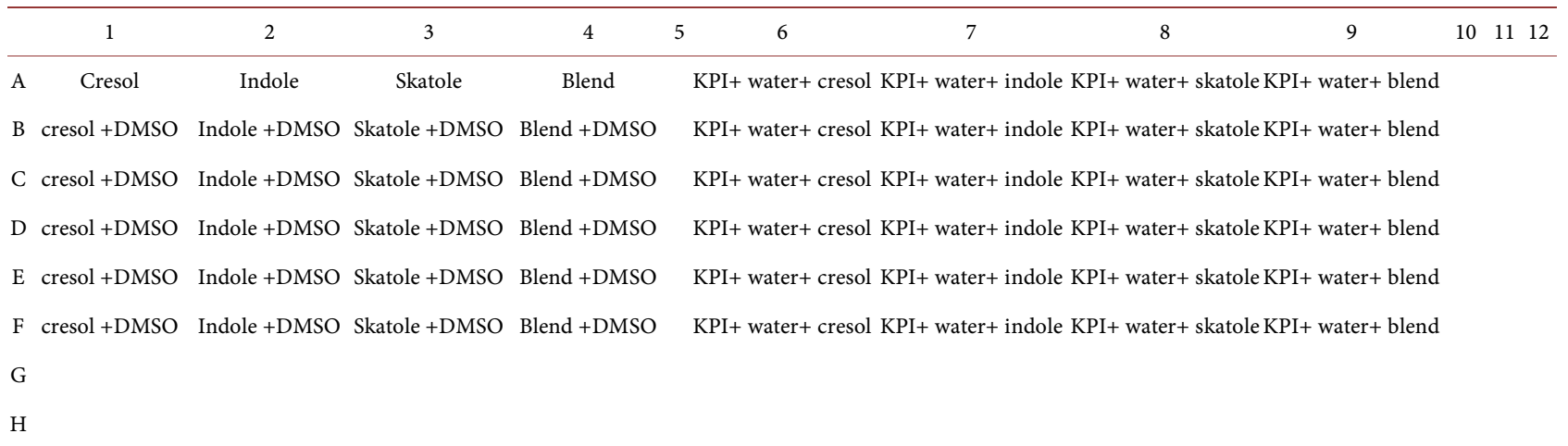


$\%$ of inhibition $=100-(($ amount of inhibition $/$ mean value of the positive control) $\times 100)$.

\subsection{CYP1B1 Assays}

In a new clear 96 well plate put cresol, indole, skatole and blend in the first four wells individually and as before Insert $200 \mu \mathrm{L}$ of $2 \mathrm{mM}$ of stock from the first raw and transfer from it $100 \mu \mathrm{L}$ in $100 \mu \mathrm{L} 10 \%$ DMSO in to the second raw then transfer $100 \mu \mathrm{L}$ in $100 \mu \mathrm{L}$ of DMSO in the third raw then transfer $20 \mu \mathrm{L}$ from the third raw to the forth raw with $180 \mu \mathrm{L}$ of DMSO, then transfer from it $100 \mu \mathrm{L}$ in $100 \mu \mathrm{L}$ in $10 \%$ DMSO to the fifth raw then transfer $100 \mu \mathrm{L}$ in $100 \mu \mathrm{L}$ of DMSO in the sixth raw then add $20 \mu \mathrm{L}$ in $180 \mu \mathrm{L}$ of $10 \%$ DMSO in the $7^{\text {th }}$ raw and in the $8^{\text {th }}$ raw transfer $100 \mu \mathrm{L}$ in $200 \mu \mathrm{L}$ DMSO.

In the next successive four wells dilute with $60 \mu \mathrm{L}$ water and $80 \mu \mathrm{L}$ of $200 \mathrm{mM}$ KPI and pipette $20 \mu \mathrm{L}$ cresol from the first column with them in the $6^{\text {th }}$ column, $20 \mu \mathrm{L}$ indole from second column in the $7^{\text {th }}$ column, $20 \mu \mathrm{L}$ skatole from the third column in the $8^{\text {th }}$ column and $20 \mu \mathrm{L}$ blend from the $4^{\text {th }}$ column in $9^{\text {th }}$ column.

Prepare master mix from CYP $1 \mathrm{~B} 1$ and KPI by the ratio 1:130.

$1 \mu \mathrm{L} \mathrm{CYP} 1 \mathrm{~B} 1 * 130=130 \mu \mathrm{L}$;

$9 \mu \mathrm{L} \mathrm{KPI}{ }^{\star} 130=1170 \mu \mathrm{L}$.

In Eppendorf tube prepare CYP mix by mixing $1170 \mu \mathrm{L}$ of $100 \mathrm{mM}$ KPI and $130 \mu \mathrm{L}$ of CYP $1 \mathrm{~B} 1$ and pipette $10 \mu \mathrm{L}$ in each well of a black 96 well plate.

In the black 96 well plate:

take $40 \mu \mathrm{L}$ of the $6^{\text {th }}$ clear column and transfer it into black columns 1, 2 and 3 , take $40 \mu \mathrm{L}$ of the $7^{\text {th }}$ clear column and transfer it into black columns 4,5 and 6 , take $40 \mu \mathrm{L}$ of the $8^{\text {th }}$ clear column and transfer it into black columns 7,8 and 9 , take $40 \mu \mathrm{L}$ of the $9^{\text {th }}$ clear column and transfer it into black columns 10,11 and 12.

In the last raw $\mathrm{H}$ keep the first 6 wells as positive control and in the next 6 wells pipette $70 \mu \mathrm{L}$ stop solution of acetonitrile to kill enzyme as a negative control.

Prepare master mix in a petri dish which consists of:

$3250 \mu \mathrm{L} 200 \mathrm{mM}$ potassium phosphate buffer;

$70 \mu \mathrm{L} 1 \mathrm{mM}$ stock EROD substrate;

$650 \mu \mathrm{L}$ solution $\mathrm{A}$;

$130 \mu \mathrm{L}$ solution $\mathrm{B}$;

$2405 \mu \mathrm{L}$ distilled water.

Mix them gently and pipette $50 \mu \mathrm{L}$ to each well in 96 black well plate then measure the rate of inhibition using gen5 software and wait for about $20 \mathrm{~min}$. Transfer your data into excel sheet and divide data related to blend on 3 to obtain the inhibition effect of each chemical individually within the combination. Calculate the mean, standard deviation and standard error of the mean for both positive and negative control values. Calculate the percentage of inhibition. 


\subsection{Statistical Analysis of CYP450s}

Using graph pad insert the data from excel sheet to draw the curve illustrating the relative fluorescence units (RFU) versus concentration by $\mu \mathrm{M}$ showing the inhibition of these chemical to microsomal enzymes CYPs.

\section{Results}

\subsection{CYP450 Inhibition}

\subsubsection{CYP1A2 Assays}

The results obtained in the tables below illustrate final well concentrations by $\mu \mathrm{M}$, inhibition values, and percentage of inhibition according to the equation:

$\%$ of inhibition $=100-(($ amount of inhibition $/$ mean value of the positive control) $\times 100$ ).

The results of CYP1A2 inhibition assays are illustrated below (Table 4):

For positive controls the mean value $=21,402.2222$, standard deviation $=$ 1551.13183 and $\mathrm{SEM}=517.043942$.

For negative controls mean value $=791.666667$, standard deviation $=$ 51.0718448 and $\mathrm{SEM}=17.0239483$.

\subsubsection{CYP1A1 Assays}

The results of CYP1A1 inhibition assays are illustrated below (Table 5):

For positive controls the mean value $=98.56482$, standard deviation $=$ 11.3913778 and $\mathrm{SEM}=4.65051051$.

For negative controls the mean value $=0.092593$, standard deviation $=$ 0.03950135 and $\mathrm{SEM}=0.01612636$.

Table 4. Inhibition values related to CYP450 1A2 under the effect of cresol, indole, skatole and blend with calculated percentage of inhibition.

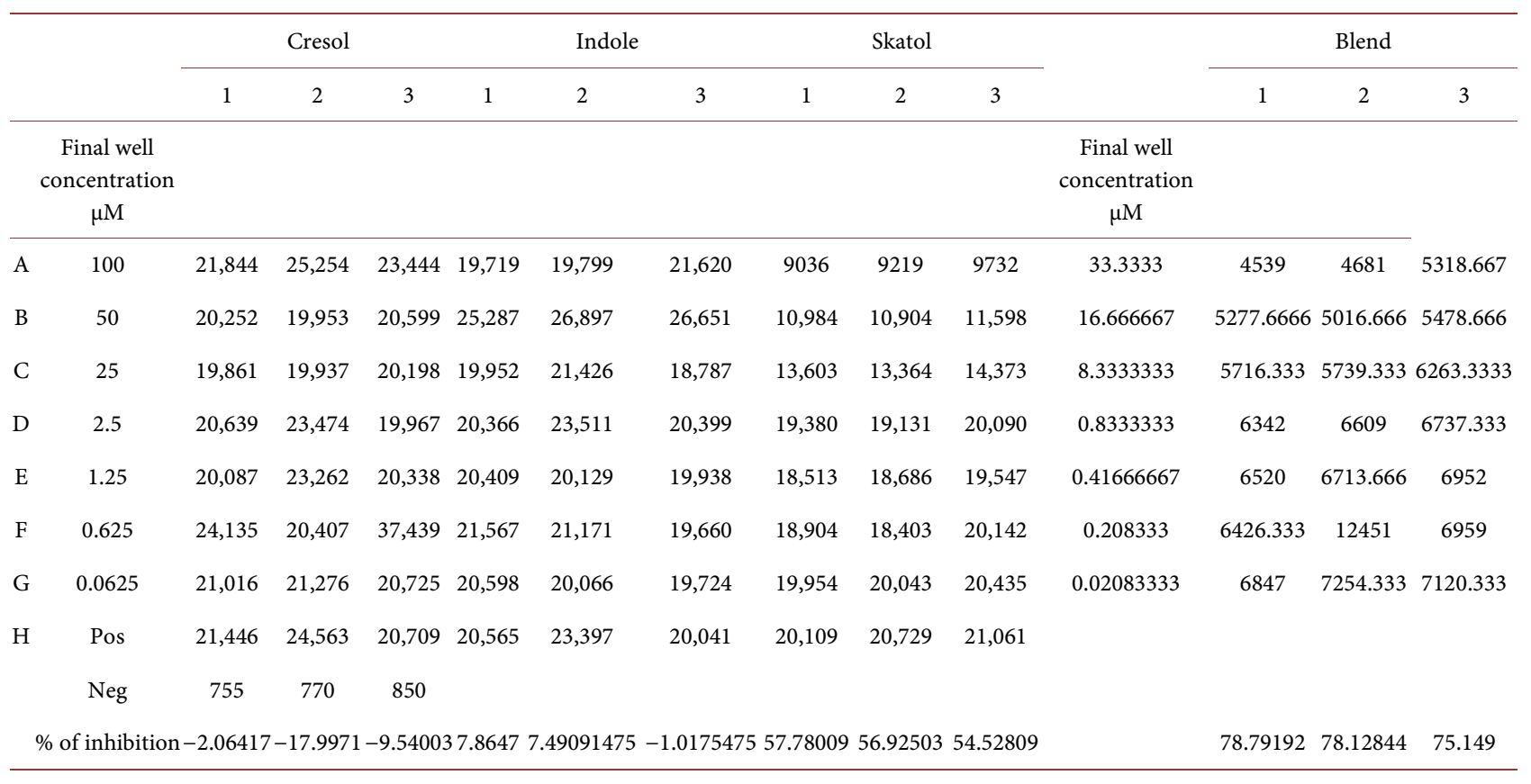


Table 5. Inhibition values related to CYP450 1A1 under the effect of cresol, indole, skatole and blend with calculated percentage of inhibition.

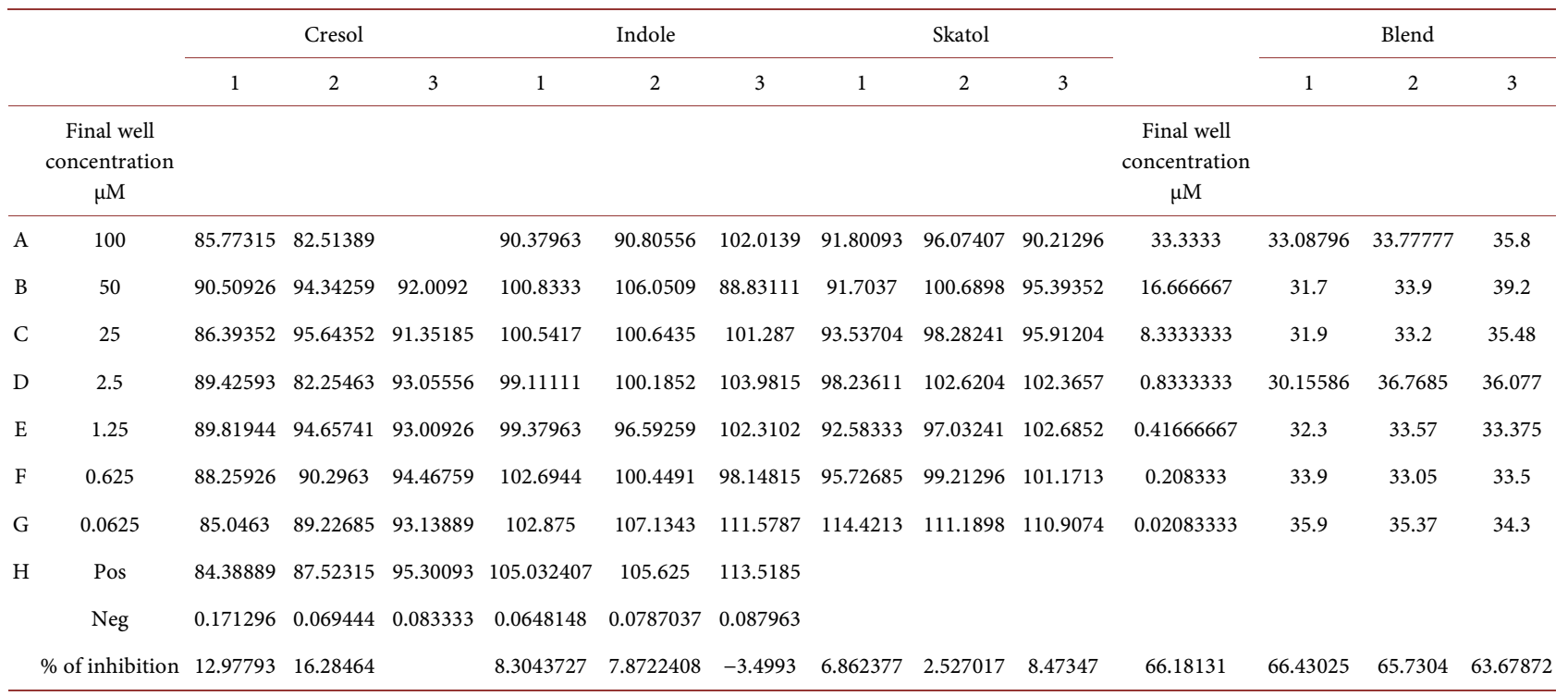

\subsubsection{CYP1B1 Assays}

In this case take skatole inhibition values only into considerations because it has high inhibition effect comparable to blend.

The results of CYP1B1 inhibition assays are illustrated below (Table 6):

For positive controls the mean value $=76,565.5$, standard deviation $=$ $19,608.78$ and SEM $=8005.25148$.

For negative controls the mean value $=2456.333$, standard deviation $=$ 899.8417 and SEM = 367.358832.

\subsection{Statistical Analysis of CYP450s}

For CYP1A2 it showed high inhibition of skatole as IC50 equals $25.85 \mu \mathrm{M}$ where its range is between 17.6 $\mu \mathrm{M}$ to $37.95 \mu \mathrm{M}$ as shown below (Figure 4).

For CYP1B1 it showed high inhibition of skatole as IC50 equals $39.76 \mu \mathrm{M}$ where its range is between $13.41 \mu \mathrm{M}$ to $117.9 \mu \mathrm{M}$ as shown below (Figure 5).

\section{Discussion}

For the graph pad related to CYPs enzymes it was shown that skatole is an inhibitor for CYP1A2 and 1B1 and according to Gene5 results, the percentage of inhibition of blend is much higher than the percentage of inhibition related to indole, skatole and cresol individually which supports the synergistic effect of their combination.

Skatole in this case is more potent inhibitor especially to CYP1A2 so skatole may be an inhibitor against anticancer drugs metabolised by CYP1A2.

For chemicals, the blend of indole, skatole and cresol can be used for topical uses to protect the body against dermatological disturbances. This blend can be used topically as patches, ointments or creams especially for some dermatologic disorders. 
As well as using it for plants as onions to repel Aspergillus Fumigatus which infects plants especially onions, the physical properties of these chemicals can be beneficial if they were used as spray to repel insects as flies and mosquitoes.

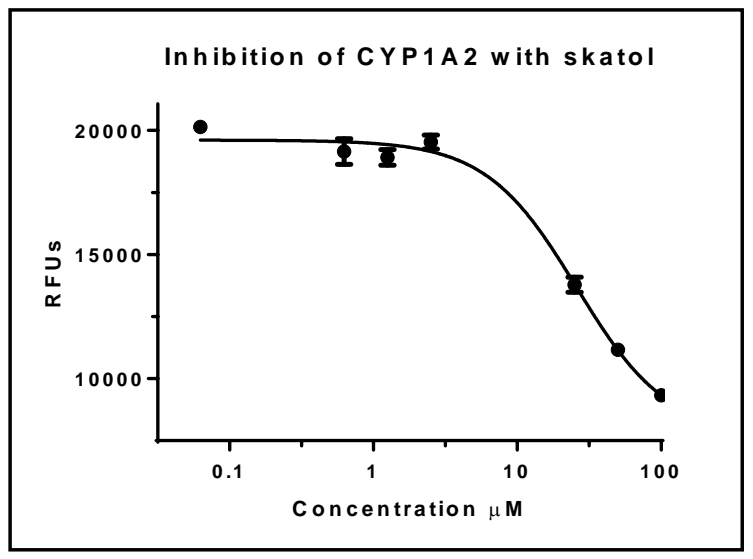

Figure 4. GraphPad shows RFU by Nano meter against log of skatole related to CYP1A2.

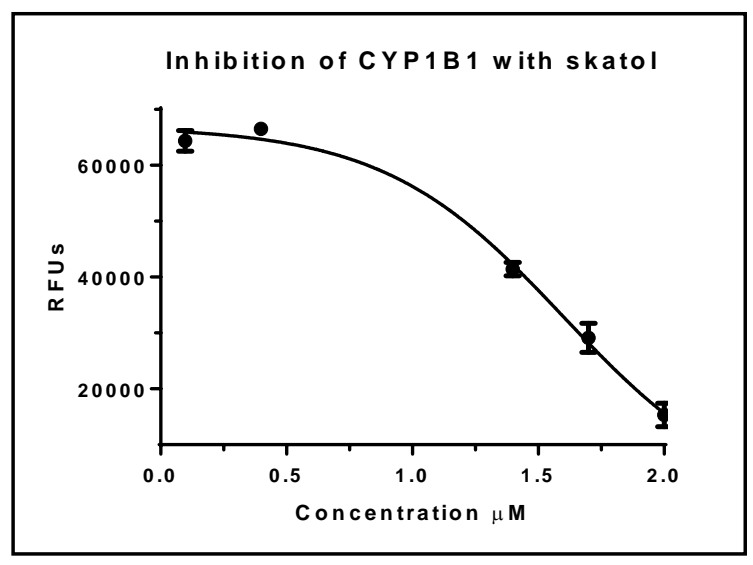

Figure 5. GraphPad shows RFU by Nano meter against log of skatole related to CYP1B1.

Table 6. Inhibition values related to CYP450 1B1 under the effect of skatole and blend with calculated percentage of inhibition.

\begin{tabular}{|c|c|c|c|c|c|c|c|c|c|}
\hline & \multicolumn{3}{|c|}{ 09-Jul. } & \multicolumn{3}{|c|}{ Skatole } & \multicolumn{3}{|c|}{ Blend } \\
\hline & & $\mu \mathrm{M}$ & & & & & & & \\
\hline & $\mathrm{A}$ & 100 & 11,155 & 17,329 & 17,509 & 33.3333 & 19,865 & 20,600 & $21,622.33$ \\
\hline & B & 50 & 23,907 & 31,915 & 31,490 & 16.666667 & $21,550.33$ & $22,651.667$ & 23,404 \\
\hline & $\mathrm{C}$ & 25 & 39,020 & 42,182 & 43,045 & 8.3333333 & $21,569.67$ & 24,520 & $24,049.33$ \\
\hline & $\mathrm{D}$ & 2.5 & 67,675 & 67,304 & 64,660 & 0.8333333 & $21,917.33$ & $22,125.667$ & $24,120.67$ \\
\hline & $\mathrm{E}$ & 1.25 & 66,521 & 60,598 & 65,942 & 0.41666667 & $19,202.33$ & 20,139 & $22,126.33$ \\
\hline & $\mathrm{F}$ & 0.625 & 51,702 & 49,870 & 54,946 & 0.208333 & $15,662.33$ & $16,107.333$ & $17,791.67$ \\
\hline & G & 0.0625 & 35,367 & 28,880 & 33,246 & 0.02083333 & 9345.667 & 9542 & $11,672.33$ \\
\hline & H 1-6 & Pos & 98,315 & 92,030 & 83,020 & 76,067 & 65,857 & 44,104 & \\
\hline & H 7-12 & Neg & 1901 & 3265 & 3906 & 1821 & 1997 & 1848 & \\
\hline$\%$ of inhibition & & & 85.4 & 77.367 & 77.1 & & 74.05 & 73.09 & 71.76 \\
\hline
\end{tabular}


According to the results related to CYP450, the inhibitory effect of these chemicals especially skatole alone or blend can be useful to determine the drugdrug interactions related to taking these chemicals with other drugs which will affect their concentration as well as drug-disease interactions which were seen with patients suffer from chronic kidney diseases who cannot metabolize cresol and this substance is contraindicated to them.

\section{Conclusions}

The future work based on these results, His-tag cloning may be further done as some tags participate in the loss of activity of the peptide and optical density may be measured for measuring its inhibitory effects using $\mathrm{N}$ and $\mathrm{C}$ terminals.

Cloning and expression with yeasts can be done further with other protein peptides as lactoferrin and lactotransferrin which are found in the milk of many species of mammals and have antimicrobial activity. It can be extracted from milk of whales, camels and dolphins depending on their hydrophobicity and $\beta$-sheets which facilitates its penetration to the cell wall of microbes.

Further studies are needed to understand the overall properties of this combination and its effect against more microorganisms and its inhibitory effect on liver microsomal enzymes.

\section{Conflicts of Interest}

The authors declare no conflicts of interest regarding the publication of this paper.

\section{References}

[1] Ortiz de Montellano, P.R. (1995) Cytochrome P450: Structure, Mechanism, and Biochemistry. Kluwer Academic/Plenum Publishers, New York. https://doi.org/10.1007/978-1-4757-2391-5

[2] Vlasak, R., Unger-Ullmann, C., Kreil, G. and Frischauf, A.M. (1983) Nucleotide Sequence of Cloned cDNA Coding for Honeybee Prepromelittin. European Journal of Biochemistry, 135, 123-126. https://doi.org/10.1111/j.1432-1033.1983.tb07626.x

[3] Habermann, E. (1972) Bee and Wasp Venoms: The Biochemistry and Pharmacology of Their Peptides and Enzymes Are Reviewed. Science, 177, 314-322. https://doi.org/10.1126/science.177.4046.314

[4] von Moltke, L.L., Greenblatt, D.J., Duan, S.X., Harmatz, J.S. and Shader, R.I. (1994) In Vitro Prediction of the Terfenadine-Ketoconazole Pharmacokinetic Interaction. The Journal of Clinical Pharmacology, 34, 1222-1227. https://doi.org/10.1002/j.1552-4604.1994.tb04735.x

[5] Griffin, J.P. (1998) The Withdrawal of Mibefradil (Posicor). Adverse Drug Reactions and Toxicological Reviews, 17, 59-60. 